COVID-19

DOI: 10.31793/1680-1466.2021.26-3.248

\title{
Клінічні прояви синдрому пост-COVID-19
}

\section{М.Д. Тронько, В.Л. Орленко, Ю.В. Курінна, К.Ю. Іваськіва}

ДУ «Інститут ендокринології та обміну речовин ім. В.П. Комісаренка НАМН України»

\begin{abstract}
Резюме. На сьогодні пандемія COVID-19 триває вже близько двох років. Хоча знання фахівців значно покращились у питаннях профілактики та лікування важких форм захворювання, патогенез та лікування синдрому пост-COVID-19 залишаються актуальними питаннями в медичній та науковій спільнотах. Актуальність проблеми полягає в значному поширенні цього стану серед перехворілих, зниженні якості життя пацієнтів, нестачі знань про частоту, механізми перебігу та причини віддалених наслідків, нечітких уявленнях стосовно підходів до діагностики та лікування, а також відсутності нормативних документів щодо ведення таких пацієнтів. у серпні 2020 року британськими дослідниками вперше було запропоновано термін пост-COVID-19. Наявні дані свідчать про значні відмінності в епідеміологічних оцінках поширеності синдрому пост-COVID-19 через відмінності в методах відбору, періодах спостереження та розмірах вибірок. Частота синдрому пост-COVID-19 оцінюється в 10-35\%, тоді як для госпіталізованих пацієнтів вона може досягати й 85\%. Втомлюваність є найпоширенішим симптомом, про який повідомляється в 17,5-72,0\% випадків після перенесеного COVID-19, потім услід за задишкою, частота якої становить 10-40\%, виникають психічні проблеми, біль у грудях, нюхова і смакова дисфункція, що зустрічаються відповідно до 26, 22 та 11\% реконвалесцентів. Більше однієї третини пацієнтів із синдромом пост-COVID-19 мають вже наявні супутні захворювання, найчастіше зустрічаються гіпертонія та цукровий діабет. Опубліковані на сьогодні дані свідчать про те, що більшість пацієнтів із синдромом пост-COVID-19 мають хороший прогноз без подальших ускладнень та летальних наслідків. Більшість досліджень досі зосереджувалися на симптомах, пов'язаних із синдромом пост-COVID-19, а не на дисфункції органів. В огляді представлено аналіз досліджень щодо визначення синдрому пост-COVID-19, вивчення впливу перенесеної інфекції на різні системи органів та надано основні потенційні механізми розвитку ускладнень. Особлива увага приділена наслідкам перенесеного COVID-19 з боку ендокринних органів. Запропоновані рекомендації щодо обстеження і ведення пацієнтів із синдромом пост-COVID-19.
\end{abstract}

Ключові слова: синдром пост-COVID-19, патогенез, діагностика, клініка, лікування.

Коронавірусне захворювання COVID-19 (абревіатура від англ. Corona Virus Disease 2019) викликається $\beta$-коронавірусом SARS$\mathrm{CoV}-2$, який вперше було виявлено від пацієнтів із пневмонією невідомої на той час етіології в китайському місті Ухань у грудні 2019 року. 3 моменту появи першого зараження

๑ М.Д. Тронько, В.Л. Орленко, Ю.В. Курінна, К.Ю. Іваськіва
SARS-CoV-2 він швидко поширився від Китаю до багатьох інших країн [1].

30 січня 2020 року Всесвітня організація охорони здоров'я (BOO3, World Health Organization, WHO) оголосила спалах COVID-19 надзвичайною ситуацією у сфеpi суспільної охорони здоров'я, що має міжнародне значення, а вже 11 березня епідемія 
була названа пандемією [2]. За повідомленням ВОО3, станом на 25 вересня 2021 року, було зареєстровано 230418451 випадок захворювання на COVID-19, зокрема 4724876 смерті [3]. В Україні станом на 20 вересня 2021 року було зафіксовано 2379483 підтверджених випадків COVID-19 із 55424 летальними [4].

SARS-CoV-2 може проявлятися різним спектром форм, починаючи від безсимптомної форми, закінчуючи загрозливим для життя гострим респіраторним дистрес-синдромом або септичним шоком [5]. Однак із прогресією пандемії, клініцисти почали спостерігати тривалі наслідки та симптоми перенесеного гострого COVID-19. Все більше нових повідомлень про стійкі втому, кашель, задишку, когнітивну дисфункцію та інше з'являються в науковій літературі після перенесеного COVID-19, незалежно від його тяжкості.

Метою огляду $є$ опис наявних наукових даних про синдром пост-COVID-19, формування основних підходів до класифікації та визначення потенційних механізмів його патогенезу.

У серпні 2020 року вперше було запропоновано, що пост-COVID-19 розпочинається через 3 тижні після появи перших симптомів, a «хронічний COVID-19» - це персистенція симптомів понад 12 тижнів після перших проявів хвороби [6]. У настанові Національного інституту здоров'я і досконалості допомоги (National Institute for Health and Care Excellence, NICE), що була опублікована 18 грудня 2020 року, даються два визначення постгострого COVID-19: «тривалий симптомний COVID-19» для пацієнтів, які все ще мають симптоми між 4 та 12 тижнями після початку захворювання, i «синдром постCOVID-19» для тих пацієнтів, які все ще мають симптоми більше ніж через 12 тижнів [7].

Це практичні та корисні клінічні визначення, оскільки, з клінічної точки зору, більшість інфекцій, спричинених SARS-CoV-2, протікають безсимптомно або легко, тому 3-4 тижні - це розумний термін для визначення видужання від гострого респіраторного вірусного захворювання [8]. Цей термін підтверджується епідеміологічними даними, адже реплікаційно-компетентний вірус не був виділений через 10 днів після появи симптомів при легкій і середній формах тяжкості та через 20 днів після важкої. Середня тривалість позитивності полімеразної ланцюгової реакції в симптомних пацієнтів становить 24 дні [9], а середня тривалість серед безсимптомних - 24,5 доби [10]. Отже, ці клінічні визначення підтверджуються вірусологічними даними [11].

На сьогодні медична література на тему пост-COVID-19 включає повідомлення про суб'єктивні симптоми в пацієнтів, які одужали від різних форм важкості гострого COVID-19. Також описуються різні прояви патології внутрішніх органів після перенесеної гострої інфекції. Тому, щоб стандартизувати наше сучасне розуміння синдрому пост-COVID-19, було запропоновано поділити його прояви на такі категорії: залишкові симптоми, які зберігаються після одужання від гострої інфекції, порушення функції органів, що залишаються після одужання, і нові симптоми або синдроми, які розвиваються після початково безсимптомної або легкої інфекції [8].

\section{Стійкі симптоми після тяжкої форми COVID-19}

На сьогодні втома є одним із найбільш частих симптомів, які пацієнти відчувають після відновлення внаслідок перенесеної гострої інфекції SARS-CoV-2. Carfi et al. повідомляють про стійкі симптоми в 143 пацієнтів із COVID-19, опитаних після виписки зі стаціонару [12]. Усі пацієнти в цьому дослідженні мали негативний результат тесту полімеразної ланцюгової реакції в період спостереження. Автори відзначають, що 87\% пацієнтів мали принаймні один залишковий симптом у середньому через 60 днів після появи симптомів, при цьому найпоширенішими з них були: втома (53,1\%), задишка (43,4\%) та артралгії $(27,3 \%)$. Важливо, що більшість із тих, хто має постійні симптоми (55\%), мали їх 3 або більше, що свідчить про високий загальний тягар небажаних залишкових симптомів для пацієнтів.

У дослідженні з Великобританії шляхом телефонного опитування було оцінено 100 пацієнтів із COVID-19 у середньому через 48 днів після виписки з лікарні [13]. Зі 100 обстежених пацієнтів 32 мали необхідність перебування у відділенні інтенсивної терапії (BIT). Cередній вік серед пацієнтів становив 70,5 років, тоді як серед госпіталізованих у ВIT $-58,5$ років. Значна втома, не характерна для стану пацієнта до захворювання, також була найбільш 
COVID-19

поширеною серед пацієнтів, зокрема в тих, які перебували у BIT (72\%). Задишка була більш поширена серед пацієнтів реанімації (66\%), ніж серед пацієнтів загальнотерапевтичних палат (3ТП) (43\%). Майже половина пацієнтів, які перебували у BIT, повідомляли про симптоми посттравматичного стресового розладу. Про нові або погіршення наявних проблем із концентрацією уваги повідомляли $16 \%$ пацієнтів 3ТП та 34\% пацієнтів ВIT.

У дослідженні з Франції, при телефонному опитуванні 120 виписаних пацієнтів (96 із відділення 3ТП; 24 з ВІT) із середнім періодом спостереження 110,9 дня після надходження до стаціонару найбільш частими симптомами були: втома (55\%), задишка (42\%), втрата пам'яті (34\%), проблеми з концентрацією уваги (28\%) та розлади сну $(30,8 \%)$. Вірогідно значущої різниці в симптоматиці між пацієнтами, які потрапляли до BIT, та тими, хто потрапляв до ЗТП, не було [14].

\section{Стійкі симптоми після легкої форми COVID-19}

Згідно звіту Центру контролю та профілактики захворювань США (Centers for Disease Control and Prevention, CDC), стійкі симптоми виникали в пацієнтів із переважно легким COVID-19 [15]. Це дослідження включало 274 пацієнти, які проходили тестування на SARS-CoV-2. 3 учасниками дослідження зв'язувалися телефоном у середньому через 16 днів після тестування. Середній вік респондентів становив 42,5 роки, $52 \%$ складали жінки. Із 270 респондентів, які завершили опитування, найбільш часто повідомлялося про такі стійкі симптоми, як кашель (43\%), втому (35\%) та задишку (29\%). Усього 35\% пацієнтів повідомили, що не повернулись до свого початкового стану здоров'я. Був також вірогідно суттєвий зв'язок між наявністю хронічних захворювань та неповерненням до базового стану здоров'я. Іншими факторами ризику неповернення до звичного стану здоров’я стали ожиріння та наявність психічного захворювання.

\section{Дисфункція органів після COVID-19}

Прояви гострого COVID-19 на різні системи органів є добре описаними [16]. Однак на сьогодні вже досить часто повідомляється про персистентні порушення функцій органів після гострої фази цього захворювання.
Симптоми, які відмічають пацієнти після перенесеної гострої інфекції, дуже різні й, зокрема, включають: загальні (гарячка, біль і втомлюваність), прояви з боку дихальної системи (кашель і задишка), з боку серцево-судинної системи (стискання і біль у грудній клітці та посилене серцебиття), неврологічні (нейрокогнітивні розлади, порушення концентрації уваги та пам'яті, головні болі, порушення сну, симптоми периферичної нейропатії: поколювання й оніміння й запаморочення), з боку шлунково-кишкового тракту (біль у животі, нудота, діарея, порушення апетиту, включаючи анорексію), з боку опорно-рухового апарату (біль у м’язах і суглобах), психічні (депресія та тривога), із боку ЛОР-органів (біль у вухах, шум у вухах, порушення нюху і смаку та біль у горлі) і шкірні (висип) [7].

Отож, особливість синдрому постCOVID-19 полягає в тому, що він впливає на тих, хто пережив COVID-19, при будь-якому ступені тяжкості захворювання. Дослідження показали, що тривалий COVID вражає навіть пацієнтів із легким та середнього ступеня тяжкості перебігом захворювання та молодих людей, які не потребували підтримки дихання, госпіталізації чи інтенсивної терапії. Розглянемо відомі на сьогодні наслідки перенесеного COVID-19 на різні системи органів.

Органи дихання і синдром пост-COVID-19

У гострій фазі зараження SARS-CoV-2 класифікація тяжкості захворювання переважно залежить від важкості легеневих проявів. У звіті, отриманому при обстеженні 72314 пацієнтів із Китаю, зазначено, що важкий перебіг інфекції був у 14\% пацієнтів, критичний у 5\% [17]. Гострий респіраторний дистрес синдром - ще один клінічний прояв важкого або критичного COVID-19. В одному з перших звітів, що описують 138 госпіталізованих пацієнтів з Уханю, Китай, цей синдром трапився в 19,6\% пацієнтів [18].

Стосовно періоду після одужання, у дослідженні зі 110 госпіталізованими пацієнтами, що перехворіли на гострий COVID-19, тести легеневої функції проводили або в день виписки з лікарні або за 1 день до цього [19]. Це тестування зафіксувало відхилення в дифузійній здатності легень до вуглекислого газу (diffusing capacity of the lungs for carbon 
monoxide, DLCO), при цьому 47,2\% пацієнтів мали $<80 \%$ передбачуваної DLCO. Зменшення показника частіше спостерігається серед пацієнтів, які перенесли захворювання важче. Загалом 30,4\%, 42,4\% та 84,2\% відповідно серед осіб із легким захворюванням, пневмонією та важкою пневмонією мали порушення в DLCO $(\mathrm{p}=<0,5)$. Опис симптоматики пацієнтів не було подано в це дослідження, тому адекватно зіставити DLCO з об'єктивними даними неможливо.

Додатково проведено окреме дослідження на 13 пацієнтах із тестуванням легеневих функцій після клінічного одужання від COVID-19 (за день до виписки з лікарні) та через 6 тижнів після виписки. Вони показали рестриктивний характер змін у 10 з 13 пацієнтів із покращенням через 6 тижнів [20]. Однак форсована життєва ємність все ж була нижчою за нижню межу норми через 6 тижнів після виписки.

В іншому дослідженні також спостерігалося зниження дифузійної здатності легенів, що корелювало з рентгенологічними відхиленнями в $42 \%$ тих, хто одужав від COVID-19, через три місяці після виписки з лікарні, незалежно від початкової тяжкості захворювання [21]. Навіть через шість місяців після появи симптомів рентгенологічні аномалії легенів все ще були присутні приблизно в половини тих обстежених пацієнтів [22].

У багатьох інших повідомленнях також виявлено рентгенологічні докази фіброзу легенів тривалістю до шести місяців серед тих, хто пережив COVID-19 після виписки з лікарні, що також корелювало з початковою тяжкістю захворювання [23-28]. Тому в пацієнтів із підозрюваним синдромом пост-COVID-19 варто виключати зниження життєвої ємності легень.

Серцево-судинна система і синдром постCOVID-19

У звіті про 138 госпіталізованих кардіологічних пацієнтів 3 Уханю при гострому COVID-19 гострі пошкодження серця мали місце в 10 пацієнтів (7,2\%), шок - у 12 пацієнтів (8,7\%) та аритміі - у 23 пацієнтів (16,7\%) [17]. Середній рівень тропоніну I (нормальний діапазон $<26,2$ пг/мл) становив 6,4 нг/мл у всіх госпіталізованих пацієнтів і 11,0 пг/мл у пацієнтів BIT.

У проспективному когортному дослідженні з проведенням магнітно-резонансної томографії серця були оцінені серцеві прояви пост-COVID-19 у 100 пацієнтів, що нещодавно одужали від COVID-19 (як мінімум 2 тижні від встановлення первинного діагнозу, мали полегшення респіраторних симптомів та негативний результат полімеразної ланцюгової реакції) [29]. Середній час після початку COVID-19 та проведення магнітно-резонансної томографії становив 71 день (діапазон 6492 дні). Порівняно з пацієнтами контрольної групи, що мали серцево-судинні фактори ризику, учасники, які одужали від COVID-19, мали фракцію викиду лівого шлуночка (57\% порівняно $362 \%$; $<0,001)$ і в них частіше виявляли підвищення тропоніну Т (>3 пг/мл) (71\% порівняно з 31\%; p<0,001).

Незалежно від наявних коморбідностей, 78\% пацієнтів, що нещодавно одужали від COVID-19, за даними магнітно-резонансної томографії мали такі ураження серця: запалення міокарда, регіонарні рубці та посилення МР-сигналу від перикарда [29]. Більшість пацієнтів у цьому дослідженні мали безсимптомний перебіг захворювання $(\mathrm{n}=18)$, або легкий та помірний $(\mathrm{n}=49)$, тоді як третина потребувала госпіталізації. Слід зазначити, що $36 \%$ пацієнтів повідомили про постійну задишку і загальне виснаження на момент оцінки, а 16\% із них були раніше госпіталізовані. За результатами цього дослідження важко встановити, чи були ці суб'єктивні симптоми наслідками серцевих відхилень, або ж наслідками супутньої легеневої патології.

\section{Тромбоемболічний стан і синдром пост- COVID-19}

Доведено, що гостра інфекція SARS-CoV-2, особливо у важкій формі, асоціюється 3 підвищеним ризиком венозної тромбоемболії (BTE) [30]. Довгостроковий ризик ВТЕ є менш чітко вивченим.

$\mathrm{y}$ ретроспективному спостережному когортному дослідженні зі 163 пацієнтами, 3 яких 26\% вимагали госпіталізації, сукупна захворюваність на ВТЕ через 30 днів після виписки становила 0,6\% [31]. Сукупна частота всіх тромбозів (включаючи легеневу емболію, тромб лівого шлуночка, оклюзію центральної артерії сітківки, тромбоз артеріовенозної діалізної фістули та ішемічний інсульт) становила 2,5\%. У цих дослідженнях показники ВТЕ та частоти кровотеч не відрізнялись від таких, 
COVID-19

що були під час госпіталізацій з інших причин, не пов'язаних із COVID-19 [32-34].

В іншому дослідженні за участі 102 пацієнтів було виявлено низький рівень ВТЕ $(<1 \%)$ у середньому через 44 дні після госпіталізації через COVID-19 [35]. Цей висновок узгоджується з великим оглядом ВТЕ у пацієнтів із COVID-19, виписаних із лікарні Кінгс-Коледж у Великобританії [36]. У це дослідження включались ВТЕ, діагностовані в лікарні принаймні через 48 годин після надходження чи післяопераційно та до 90 днів після виписки. Загалом, 1877 пацієнтів, виписаних після госпіталізації внаслідок COVID-19, були включені в аналіз. Виявлено 84 епізоди ВТЕ, що відбулися протягом досліджуваного періоду. $11 \%$ випадків ВТЕ сталися в середньому через 8 днів після виписки. Автори підрахували частоту пацієнтів, у яких розвинулась ВТЕ, як 4,8 на 1000 виписаних. Співвідношення шансів BTE, асоційованих із COVID-19, порівняно 3 показниками, що спостерігались у 2019 році до COVID-19, було 1,6 і не виявилось вірогідно значущим.

\section{Нервова система і синдром пост-COVID-19}

Посмертні дослідження хворих на SARS показали, що вірус проникав через гематоенцефалічний бар'єр до гіпоталамуса через нюховий нерв [37]. У результаті було виявлено, що шлях цього вірусу йшов так, як це було запропоновано раніше у хворих із синдромом хронічної втоми/міалгічним енцефаломієлітом (chronic fatigue syndrome/myalgic encephalomyelitis, CFS/ME), включаючи порушення лімфодренажу з мікроглії [38].

Один 3 основних шляхів лімфодренажу головного мозку пролягає через периваскулярні простори вздовж нюхових нервів через решітчасту пластинку до слизової оболонки носа [39]. Оскільки патогенез коронавірусу відбувається подібним шляхом, він може пояснити аносмію, що спостерігається в частини хворих на COVID-19. Це порушення призводить до накопичення прозапальних цитокінів, таких як інтерферон-гамма та інтерлейкін 7 [40], для яких передбачається, що вони можуть впливати на неврологічний контроль «лімфатичної системи», як це спостерігається в CFS/ME [41].

Накопичення цитокінів у центральній нервовій системі може призводити до поствірусних симптомів шляхом їх скупчення навколо шлуночків мозку і в гіпоталамусі, що призводить до вегетативної дисфункції, яка може проявлятись підвищенням температури, а в довгостроковій перспективі - порушенням регуляції сну/неспання, когнітивної дисфункції та значної втоми. Оскільки це трапилось після спалаху SARS, то і частка пацієнтів, які постраждали від COVID-19, можуть перейти в поствірусний синдром, який ми сьогодні називаємо «синдромом пост-COVID-19».

SARS-CoV-2 проявив нейротропні властивості та приблизно в $36 \%$ пацієнтів із COVID-19 розвиваються неврологічні ознаки й такі симптоми, як головний біль, енцефалопатія та парестезії [42]. Також були задокументовані випадки підтвердженого вірусного енцефаліту, спричиненого SARS-CoV-2 [43]. Зокрема, було виявлено пошкодження кардіореспіраторного центру в стовбурі мозку у хворих на COVID-19 [44]. Оскільки нейрони рідко регенерують, дисфункція стовбура мозку може бути тривалою, що призводить до неврологічних та кардіореспіраторних наслідків, які, ймовірно, можуть лежати в основі синдрому пост-COVID-19 [45, 46].

Стовбур мозку експресує вищі рівні ангіотензинперетворюючого ферменту 2 (АПФ2, angiotensin I converting enzyme 2, ACE2), рецептора до SARS-CoV-2, ніж інші ділянки мозку [47]. У протоколах розтинів також були знайдені докази наявності генів та білків SARS-CoV-2 у стовбурі мозку померлих жертв COVID-19 [48-50]. Тому тривалі нейрозапальні процеси можуть викликати неврологічні симптоми та пошкодження протягом тривалого часу після перенесеного COVID-19.

\section{Нирки та синдром пост-COVID-19}

Гостре пошкодження нирок (ГПН) добре описане як потенційне ускладнення в госпіталізованих пацієнтів через важкий COVID-19 із частотою 37-40\% у Сполучених Штатах Америки $[51,52]$. Менше відомостей щодо довгострокового відновлення функції нирок після гострого періоду.

Після обстеження 9657 пацієнтів, які поступили в стаціонар із COVID-19 протягом березня та квітня 2020 року, було виявлено, що ГПН (як із необхідністю замісної ниркової терапії, так і без неї) було суттєво пов'язано з ризиком смерті [53]. Автори також зазначають, що 31\% 
зі 108 пацієнтів із ГПН, яким була потрібна така терапія, залишались на діалізі під час виписки, що свідчить про тривалість порушення функції нирок попри вирішення гострої інфекції COVID-19. У 36,9\% пацієнтів із ГПН, які не потребували замісної ниркової терапії, спостерігалася дисфункція нирок на момент виписки з лікарні.

B епоху до COVID-19 було показано, що ГПН асоційоване зі збільшенням смертності та підвищеним ризиком виникнення хронічної хвороби нирок de пого [54].

\section{Ендокринні залози та синдром пост- COVID-19}

Система гіпофіз-гіпоталамус-наднирники

На цей момент відсутні дані про прямий ефект вірусу COVID-19 на гіпофіз або гіпоталамус, однак автори описали докази впливу SARS на них у дослідженні за участі 61 пацієнта [55]. 40\% тих, хто вижив, мали біохімічні докази центральної надниркової недостатності, більшість 3 яких були зворотні та протягом року вирішились. Запропонованим механізмом розвитку був гіпофізит або пряме ураження гіпоталамусу вірусом.

Показано, що антитіла, які виробляються проти вірусу, руйнують адренокортикотропний гормон і призводять до притуплення реакції кортизолу на стрес [56]. Базуючись на попередньому досвіді із SARS, геномну подібність цих коронавірусів, ми можемо припустити, що COVID-19 здатен впливати на вісь гіпоталамус-гіпофіз і ми повинні мати низький поріг підозри на центральну адренокортикотропну недостатність у пацієнтів із синдромом пост-COVID-19 [57, 58].

\section{Система гіпофіз-щитоподібна залоза}

Зараз недостатньо даних щодо впливу COVID-19 на щитоподібну залозу (Щ3). Рецептори АПФ2, як місце входу COVID-19, розташовані й в Щ3 [59]. Описані випадки розвитку підгострого тиреоїдиту в пацієнтів iз діагнозом гострої інфекції COVID-19 та в період реконвалесценції [60-62]. Враховуючи, що етіологію підгострого тиреоїдиту приписують вірусним інфекціям, не дивно, що COVID-19 також здатен його спричинити.

У дослідженні THYRCOV проводили оцінку функції Щ3 в пацієнтів із COVID-19, виходячи 3 гіпотези, що «цитокіновий шторм», пов'язаний із COVID-19, може вплинути на функцію ЩЗ та/або важкий гострий респіраторний синдром коронавірус 2 (SARS-CoV-2), а також на клітини ЩЗ, як це було раніше продемонстровано щодо інфекції SARS-CoV-1.

Ретроспективно проводилась оцінка функціональних тестів Щ3 та показників сироваткового інтерлейкіну-6 у 287 пацієнтів, госпіталізованих із COVID-19 у відділення інтенсивної терапії [63]. У 58 пацієнтів (20,2\%) було виявлено тиреотоксикоз, у 15 (5,2\%) гіпотиреоз та 214 (74,6\%) мали нормальну функцію ЩЗ. У багатоваріантному аналізі тиреотоксикоз виявився значною мірою асоційованим із високим рівнем інтерлейкіну-6.

Таким чином, дослідження дає перші докази того, що COVID-19 може бути пов'язаний із високим ризиком розвитку тиреотоксикозу у зв’язку з системною імунною активацією, спричиненою інфекцією SARS-CoV-2. Важливо зазначити, що хоча інфекції пов’язують із генезом автоімунних захворювань ЩЗ, досі не було показано, що наявність автоімунного захворювання ЩЗ призводить до підвищеної схильності до інфекційних хвороб загалом та COVID-19 зокрема.

\section{Система гіпофіз-гонади}

Дані щодо впливу COVID-19 на жіночі статеві залози й репродуктивну функцію обмежені. Нещодавно припускали, що COVID-19 може атакувати тканини яєчників та ендометрій через експресію АПФ2 в цих тканинах [64, 65]. Jing et al. надали глибокий огляд потенційних мішеней COVID-19, які можуть впливати на репродуктивне здоров'я, також відзначаючи експресію АПФ2 в ооцитах, яєчниках, матці та піхві [66].

Чоловіки з COVID-19 мають вищий ризик несприятливих наслідків та смерті порівняно 3 жінками попри однакову поширеність інфекції [67]. Статеві відмінності імунної відповіді загалом (не специфічні для COVID-19) вивчались давно. Хоча процес складний, експерти зазначають, що дорослі жінки виявляють сильнішу вроджену та адаптивну імунну відповідь, ніж чоловіки, що згодом приводить до швидшого очищення від патогенних мікроорганізмів, але сприяє їх підвищеній сприйнятливості до запальних та автоімунних захворювань [68].

Дослідження самців і самок мишей, інфікованих SARS, показало, що миші-самці були 
COVID-19

більш сприйнятливими до зараження порівняно з самками [69]. Автори підкреслюють захисний ефект естрогену в самок, відзначаючи збільшення смертності мишей після оваріектомії або лікування антагоністом рецепторів естрогену. В іншому дослідженні на мишах, інфікованих вірусом грипу А, було встановлено, що оваріектомовані самки мишей, які отримували естрадіол, мали меншу ступінь тяжкості захворювання з меншою захворюваністю порівняно з мишами, які отримували плацебо попри однакові титри вірусу [70]. Це галузь майбутніх досліджень у спробі зрозуміти різницю щодо тяжкості між чоловіками та жінками з COVID-19.

АПФ2 експресується в яєчках людини, насамперед у сперматогоніях, клітинах Лейдіга та клітинах Сертолі [71]. Рівень експресії там, мабуть, найвищий в організмі [72]. Крім того, клітинна трансмембранна серинова протеаза (transmembrane protease, serine 2, TMPRSS2), також важлива для вірусного проникнення до клітини, теж присутня в яєчках [73]. Клітини Лейдіга виробляють тестостерон, а клітини Сертолі взаємодіють зі сперматогенними клітинами, здійснюючи контроль диференціації клітин сперми.

COVID-19 поділяє 76\% амінокислотної послідовності з SARS, який спричиняв орхіт та значне руйнування статевих клітин у яєчках людини [74]. Отже, існує можливість того, що COVID-19 проникає в яєчка через АПФ2 і перешкоджає вивільненню тестостерону та виробленню сперми, тим більше, що кров’янояєчковий бар'єр може порушуватися при наявності системного або місцевого запалення.

E кілька повідомлень про дискомфорт у ділянці мошонки, навіть сильний біль у мошонці в людей із COVID-19 та одне повідомлення про випадок орхіепідидиміту [75-77].

Рівні тестостерону, лютеїнізуючого гормону, фолікулостимулюючого гормону та пролактину вимірювали у 81 госпіталізованих із підтвердженим COVID-19 пацієнтів у віці від 20 до 54 років із середнім віком 38 років [78]. Контрольну групу складали чоловіки відповідного віку, яким раніше проводили оцінку репродуктивної функції та які вважалися здоровими з нормальною фертильністю. Важливо пам'ятати, що будь-яка гостра хвороба може знизити рівень тестостерону.
Тестостерон номінально, але не суттєво знижувався в пацієнтів із COVID-19 порівняно 3 контролем, однак рівень лютеїнізуючого гормону був значно вищим. Співвідношення тестостерону до лютеїнізуючого гормону було значно нижчим в інфікованих осіб. Ця картина підвищеного рівня лютеїнізуючого гормону із вірогідно незмінним тестостероном є такою, що може спостерігатися при ранній недостатності статевих залоз і говорить про прямий ефект COVID-19 на гіпоталамус або гіпофіз i, ймовірно, на клітини Лейдіга чоловічих гонад. Фолікулостимулюючий гормон залишався без змін. Цей ефект на яєчка може бути спричинений прямим пошкодженням яєчка вірусом або непрямою імунною реакцією [79].

Сперму досліджували на мРНК COVID-19 у 12 постраждалих чоловіків у віці від 22 до 38 років та в зразках яєчок 67-річного чоловіка, який помер [80]. Жоден зі зразків не був позитивним щодо мРНК COVID-19. В іншому дослідженні також не було виявлено мРНК COVID-19 у спермі 34 чоловіків, зібраних між 8 i 75 днями після діагностики COVID-19 [81].

Пацієнти 3 середньо-важкою інфекцією мали вірогідно значуще погіршення якості сперми (концентрація сперми, загальна кількість сперми в еякуляті, загальна кількість моторики, що прогресує, та загальна кількість повної моторики) порівняно з чоловіками, які одужали.

Вищенаведені дані можуть свідчити про доцільність виключення первинного гіпогонадизму в пацієнтів із підозрюваним синдромом пост-COVID-19.

\section{Підилункова залоза та синдром пост- COVID-19}

Між COVID-19 та цукровим діабетом (ЦД) існує двоспрямована залежність. 3 одного боку, ЦД асоціюється з підвищеним ризиком розвитку тяжкого перебігу COVID-19. 3 другого боку, у хворих на COVID-19 часто спостерігаються вперше виявлений ЦД та важкі метаболічні ускладнення вже наявного захворювання, включаючи діабетичний кетоацидоз та гіперосмолярність, для контролю яких необхідні надзвичайно високі дози інсуліну [82-84].

Такі клінічні прояви вказують на складну патофізіологію ЦД, пов'язаного з COVID-19. Оскільки SARS-CoV-2 зв'язується з рецептором АПФ2, який експресується в ключових 
метаболічних органах і тканинах, включаючи $\beta$-клітини підшлункової залози, жирову тканину, клітини тонкої кишки та нирок, цілком імовірно, що SARS-CoV-2 та терапія, що використовується для його лікування, може спричинити плейотропні зміни метаболізму глюкози і ускладнювати патофізіологію вже наявного ЦД або призводити до нових механізмів захворювання [85].

Описані випадки ЦД, схильного до кетозу, які були викликані іншими коронавірусами, що зв’язуються з рецепторами АПФ2. У пацієнтів із пневмонією, викликаною SARS, спостерігались більш часті випадки підвищеної глікемії натще, ніж серед хворих на пневмонію некоронавірусної етіології [86]. У сукупності ці спостереження підтверджують гіпотезу про потенційний діабетогенний ефект COVID-19, крім загальновизнаної реакції на стрес, пов’язаної з важкою хворобою, і відповіді на глюкокортикоїдну та противірусну терапію. Однак незрозуміло, чи зберігаються зміни порушення обміну глюкози в пацієнтів, які одужали від COVID-19 і страждають на синдром пост-COVID-19.

Для розв'язання цього питання міжнародна група провідних дослідників ЦД, що беруть участь у проєкті CoviDIAB (Global Registry of COVID-19-related diabetes), створила глобальний реєстр пацієнтів із ЦД, пов’язаним із COVID-19 [87]. Метою реєстру є встановлення ступеня та фенотипу вперше виявленого ЦД, який визначається гіперглікемією, підтвердженим COVID-19, негативною історією Цд в анамнезі та нормальним рівнем глікованого гемоглобіну до хвороби. Він може бути використаний для дослідження епідеміологічних особливостей та патогенезу ЦД, пов’язаного з COVID-19, і його впливу на персистування симптомів після одужання від гострих проявів.

Інші клінічні синдроми, пов'язані із синдромом пост-COVID-19

Задокументовано численні випадки мультисистемного запального синдрому, що виникають через 2-6 тижнів після зараження SARSCoV-2 в дітей та дорослих. Ці пацієнти не обов'язково мають позитивний статус SARSCoV-2 або важке респіраторне захворювання. Проте, вони показали підвищений рівень системних маркерів запалення (наприклад,
C-реактивного білка, інтерлейкіну-6, феритину та D-димеру), серцеві, шлунково-кишкові чи неврологічні симптоми [88-92].

Затримка проявів мультисистемного запального синдрому після зараження SARS$\mathrm{CoV}-2$ свідчить про залучення до цього порушення адаптивної імунної системи, зокрема, автоантитіл [93]. Можливо, що залишкове запалення та симптоми після SARS-CoV-2 призводять до тривалого COVID-19 у дітей та дорослих.

Дійсно, підвищення рівня маркерів запалення (наприклад, С-реактивного білка, інтерлейкіну-6 і Д-димеру) та лімфопенії було пов'язано з синдромом пост-COVID-19. Досить цікаве рентгенологічне дослідження виявило, що в людей, які одужали від COVID-19 та в яких симптоми зберігались протягом $\geq 30$ днів після виписки, збільшене поглинання 18-флуородеоксиглюкози. Це означає наявність постійного запалення в кістковому мозку та кровоносних судинах [94].

Виявлено підвищений рівень судинних прозапальних біомаркерів, що корелював із легеневим ушкодженням серед пацієнтів із COVID-19, виписаних за три місяці до цього [95]. Однак існують і інші дослідження пост-COVID-19, які не виявили зв'язку з прозапальними біомаркерами. Ці дані свідчать про те, що довготривале запалення може лише частково пояснити патофізіологію синдрому пост-COVID-19 [96, 97].

Ще одне можливе джерело запалення при тривалому COVID може знаходитися в кишківнику. Відомо, що SARS-CoV-2 ефективно розмножується в клітинах шлунка та кишківника завдяки високій експресії рецепторів 2 в них, що призводить до посилення фекального виділення SARS-CoV-2 в пацієнтів [98-100]. Хоча поширеність симптомів з боку шлунковокишкового тракту може змінюватись між різними дослідженнями, виявлено, що ці прояви (наприклад, втрата апетиту, нудота, блювота, діарея та дискомфорт у животі) зустрічаються в 10-20\% пацієнтів із COVID-19 [101, 102].

Важливо, що шлунково-кишкові симптоми також були зареєстровані приблизно в третини осіб із тривалим COVID-19 [103105]. Порушення мікробіому кишківника спостерігалося серед пацієнтів із COVID-19, яке зберігалося протягом 10-30 днів після 
COVID-19

одужання [106, 107]. У цих дослідженнях дисбактеріоз також корелював зі зростанням тяжкості COVID-19, запальними біомаркерами та тривалим виділенням SARS-CoV-2 3 калом. Оскільки кишківник тісно переплетений 3 імунною системою та нейромедіаторами, порушення мікробіому після перенесеного COVID-19 може робити свій внесок у розвиток синдрому пост-COVID-19.

Потенційні механізми розвитку синдрому пост-COVID-19

Враховуючи широкий спектр гострих клінічних проявів COVID-19, механізми постCOVID-19, імовірно, багатофакторні. Наприклад, при SARS-CoV вірус має потенціал до прямої нейроінвазії та відомо, що саме ця здатність призводить до стійких нервово-психічних наслідків [108].

Одним із запропонованих механізмів стійких наслідків SARS-CoV та SARS-CoV-2 є добре описаний, індукований вірусами «цитокіновий шторм» та дисрегуляція імунної відповіді [109]. Крім того, важливо зауважити, що компетентний до реплікації вірус рідко виділяється через 20 днів після настання перших симптомів [9]; це свідчить про те, що стійкі симптоми зумовлені, в основному, імунологічними явищами.

Іншим можливим поясненням може бути персистування реплікації вірусу в місцях, прихованих від імунної системи, де він є захищеним. Також у патологоанатомічному дослідженні гістологічних зразків легеневої тканини було виявлено важкі ураження ендотелію поряд із дифузним тромбозом і мікроангіопатією [110]. Тому ушкодження ендотелію та тривала його дисфункція можуть також відігравати певну роль у тривалій симптоматиці та порушенні функції органів.

Показано, що синдром активації тучних клітин може лежати в основі патофізіологічного генезу пост-COVID-19 [111, 112]. Тучні клітини служать фактором активації фібробластів, що може призвести до фіброзу легенів, як це спостерігається у хворих із симптомами постковіду. Дійсно, було показано, що SARS-CoV-2 викликає запальні реакції тучних клітин поряд з іншими імунними клітинами в пацієнтів із COVID-19 [113, 114].

Синдром, що виникає після інтенсивної терапії, - це інший добре описаний стан, який включає симптоми стійкої когнітивної дисфункції, набуту слабкість, втому, задишку та нав’язливі спогади після виписки з лікарні, також може бути фактором, що сприяє розвитку пост-COVID-19 у пацієнтів, що перебували y BIT [115].

Ще багато чого слід дізнатись про взаємодію всіх цих факторів, потенційно нові фактори та їх відносний внесок у стійкі симптоми та порушення функції органів після гострого COVID-19. Імунологічне походження мультисистемного запального синдрому також продовжується досліджуватись.

\section{Ведення пацієнтів із синдромом пост- COVID-19}

На жаль, чітких доказових рекомендацій для клініциста досі не існує. Однак зважаючи, що синдром пост-COVID-19 спричинений комбінацією механізмів, для його лікування потрібен багатосторонній підхід до пацієнта і приділення уваги не лише фізичній стороні його здоров'я, але й когнітивній, психологічній, соціальній та професійній [7].

Пропонується, щоб пацієнти, які перенесли COVID-19, були обстежені лікарем і щоб рішення про тип лабораторних і візуалізаційних досліджень грунтувалися на інформації, отриманій у результаті детального опитування та об’єктивного обстеження. Під час збору анамнезу необхідно вияснити дату появи перших симптомів і хронологію появи нових, також потрібно запитати про симптоми нейрокогнітивних і психічних розладів, визначити, чи виникли ускладнення в ході COVID-19 (наприклад, ниркова недостатність, тромбоемболічні ускладнення тощо), на що в цей час скаржиться пацієнт, і який ступінь вираженості симптомів, дізнатись чи є супутні захворювання і якщо так, то які, та чи вплинув COVID-19 на іх перебіг і лікування.

При фізикальному обстеженні обов'язковим $є$ вимірювання температури, пульсу, тиску та насичення крові киснем. Додаткові дослідження не завжди необхідні, але можуть допомогти визначити причину симптомів і виключити тяжкі ускладнення, такі як інфаркт міокарда, тромбоемболія тощо. Також у настанові NICE щодо ведення пацієнтів із довготривалими проявами COVID-19 рекомендують негайну госпіталізацію, якщо в пацієнта із підозрюваним пост-COVID-19 є ознаки небезпечних для 
життя станів, таких як важка гіпоксемія або зниження сатурації кисню під час фізичних вправ, ознаки важкого захворювання легень, біль у грудях або прояви мультисистемного запального синдрому.

Запропоновано виконати аналізи крові (загальний аналіз крові, тести на С-реактивний білок, феритин, натрійуретичний пептид типу В (brain natriuretic peptide, BNP)) і тести для оцінки функції нирок, печінки та ЩЗ. Крім того, можна оцінити сатурацію кисню в спокої та (якщо немає протипоказань) після швидкого, наскільки це можливо, виконання присідань протягом 1 хв. Зниження сатурації на 3\% вказує на порушення і вимагає подальшої пульмонологічної діагностики. Під час цього тесту також рекомендується виміряти пульс і оцінити вираженість задишки. Особам із симптомами, що вказують на синдром постуральної ортостатичної тахікардії, наприклад, посиленим серцебиттям або запамороченням у вертикальному положенні, слід виміряти артеріальний тиск і пульс в положенні стоячи й лежачи (3-хвилинний тест активної вертикалізації, 10-хвилинний - якщо є підозра на вегетативну дисфункцію).

Терапевтична тактика залежить від виявлених порушень у конкретного пацієнта. Оскільки специфічного лікування не існує, після виключення тяжких ускладнень COVID-19 тактика грунтується на посимптомному лікуванні, спрямованому на підтримку одужання. У разі нейрокогнітивних розладів і депресії - зважити необхідність консультації психолога і психіатра.

Усім пацієнтам потрібно рекомендувати фізичну реабілітацію, зокрема виконувати легкі аеробні вправи в темпі відповідно до індивідуальних можливостей. Рівень складності вправ збільшується поступово в межах допустимих рівнів, поки не спостерігається поліпшення втоми та задишки, як правило, від чотирьох до шести тижнів. Реабілітація також включає дихальні вправи, спрямовані на контроль повільних, глибоких вдихів для посилення ефективності дихальних м'язів, особливо діафрагми. Вдих слід робити носом, надуваючи живіт, і видихати ротом. Такі легкі аеробні та дихальні вправи слід виконувати щодня через 5-10 хв протягом дня. Когнітивно-поведінкова терапія та психологічна підтримка також можуть допомогти покращити самопочуття та психічне здоров'я тих, хто одужав [116].

Вакцинація - імовірно перспективний та ефективний засіб профілактики синдрому пост-COVID-19.

\section{Висновок}

Цей огляд демонструє сучасне розуміння синдрому пост-COVID-19, відносно нового та маловивченого стану, який може вплинути на тих, хто перехворів COVID-19, незалежно від початкової тяжкості захворювання або віку. Обговорювались симптоми, епідеміологія, патофізіологія, пов'язані фактори ризику та можливе ведення таких хворих.

Однак, багато що залишається неоднозначним у цьому синдромі. Це може бути обумовлено його численним симптомокомплексом та складною патофізіологією, починаючи від мультисистемного пошкодження і закінчуючи довготривалим запаленням.

Отже, майбутні дослідження вкрай важливі для кращого розуміння пост-COVID-19. Наразі лише клінічна оцінка, посимптомне лікування та реабілітація визнані потенційно ефективними для поліпшення симптомів пост-COVID-19. Очевидно, пандемія принесла нам хвилю нового хронічного стану, який заслуговує серйозної уваги серед наукових та медичних спільнот.

\section{Список використаної літератури}

1. Ouassou H, Kharchoufa L, Bouhrim M, Daoudi NE, Imtara H, Bencheikh N, et al. The pathogenesis of coronavirus disease 2019 (COVID-19): evaluation and prevention. J Immunol Res. $2020 \mathrm{Ju}$ 10;2020:1357983. doi: 10.1155/2020/1357983.

2. World Health Organization. Rolling updates on coronavirus disease (COVID-19) 2020. Available from: https://www.who.int/ emergencies/diseases/novel-coronavirus-2019/events-as-theyhappen [Accessed 25th Sept 2021].

3. WHO. Coronavirus disease (COVID-19). Available from: https:// covid19. who.int/?gclid=EAIaIQobChMI Iat rjN7gIVDbwYCh3WXQAZEAAYASAAEgL28_D_BwE [Accessed 25th Sept 2021].

4. WHO: Ukraine. Coronavirus disease (COVID-19). Available from: https://covid19.who.int/region/euro/country/ua [Accessed 25th Sept 2021].

5. WHO. Clinical management of COVID-19. Available from: https://www.who.int/publications/i/item/clinical-managementof-covid-19 [Accessed 25th Sept 2021].

6. Greenhalgh T, Knight M, A'Court C, Buxton M, Husain L. Management of post-acute covid-19 in primary care. BMJ. 2020 Aug 11;370: m3026. doi: 10.1136/bmj.m3026.

7. Venkatesan P. NICE guideline on long COVID. Lancet Respir Med. 2021 Feb;9(2):129. doi: 10.1016/S2213-2600(21)00031-X.

8. Amenta EM, Spallone A, Rodriguez-Barradas MC, El Sahly HM, 
COVID-19

Atmar RL, Kulkarni PA. Postacute COVID-19: An overview and approach to classification. Open Forum Infect Dis. 2020 Oct 21:7(12): ofaa509. doi: 10.1093/ofid/ofaa509.

9. Xiao AT, Tong YX, Zhang S. Profile of RT-PCR for SARS-CoV-2: a preliminary study from 56 COVID-19 patients. Clin Infect Dis. 2020 Nov 19;71(16):2249-51. doi: 10.1093/cid/ciaa460.

10. Centers for Disease Control and Prevention. Duration of isolation and precautions for adults with COVID-19. Available from: https://www.cdc.gov/coronavirus/2019-ncov/hcp/durationisolation.html [Accessed 25th Sept 2021]

11. Noh JY, Yoon JG, Seong H, Choi WS, Sohn JW, Cheong HJ, et al. Asymptomatic infection and atypical manifestations of COVID-19: Comparison of viral shedding duration. J Infect. 2020 Nov;81(5):816-46. doi: 10.1016/j.jinf.2020.05.035.

12. Carfi A, Bernabei R, Landi F, for the Gemelli Against COVID-19 PostAcute Care Study Group. Persistent symptoms in patients after acute COVID-19. JAMA. 2020;324(6):603-5. doi:10.1001/jama.2020.

13. Halpin SJ, McIvor C, Whyatt G, Adams A, Harvey O, McLean L, et al. Postdischarge symptoms and rehabilitation needs in survivors of COVID-19 infection: A cross-sectional evaluation. J Med Virol. 2021 Feb;93(2):1013-22. doi: 10.1002/jmv.26368.

14. Garrigues E, Janvier P, Kherabi Y, Le Bot A, Hamon A, Gouze H, et al. Post-discharge persistent symptoms and health-related quality of life after hospitalization for COVID-19. J Infect. 2020 Dec;81(6): e4-6. doi: 10.1016/j.jinf.2020.08.029.

15. Tenforde MW, Kim SS, Lindsell CJ, Billig Rose E, Shapiro NI, Files DC, et al. Symptom duration and risk factors for delayed return to usual health among outpatients with COVID-19 in a Multistate Health Care Systems Network - United States, March-June 2020. MMWR Morb Mortal Wkly Rep. $2020 \mathrm{Jul}$ 31;69(30):993-8. doi: 10.15585/mmwr.mm6930e1.

16. Wiersinga WJ, Rhodes A, Cheng AC, Peacock SJ, Prescott HC. Pathophysiology, transmission, diagnosis, and treatment of coronavirus disease 2019 (COVID-19): A Review. JAMA. 2020;324(8):782-93. doi:10.1001/jama.2020.12839.

17. $\mathrm{Wu} \mathrm{Z}$, McGoogan JM. Characteristics of and important lessons from the coronavirus disease 2019 (COVID-19) outbreak in China: summary of a report of 72314 cases from the Chinese Center for Disease Control and Prevention. JAMA. 2020;323(13):1239-42. doi:10.1001/jama.2020.2648

18. Wang $\mathrm{D}, \mathrm{Hu} \mathrm{B}, \mathrm{Hu} \mathrm{C}$, et al. Clinical characteristics of 138 hospitalized patients with 2019 novel coronavirus-infected pneumonia in Wuhan, China. JAMA. 2020;323(11):1061-9. doi:10.1001/jama.2020.1585.

19. Mo X, Jian W, Su Z, Chen M, Peng H, Peng P, et al. Abnormal pulmonary function in COVID-19 patients at time of hospital discharge. Eur Respir J. 2020 Jun 18;55(6):2001217. doi: 10.1183/13993003.01217-2020.

20. Fumagalli A, Misuraca C, Bianchi A, Borsa N, Limonta S, Maggiolini S, et al. Pulmonary function in patients surviving to COVID-19 pneumonia. Infection. 2021 Feb;49(1):153-7. doi: 10.1007/s15010-020-01474-9.

21. van den Borst B, Peters JB, Brink M, Schoon Y, BleekerRovers CP, Schers H, et al. Comprehensive health assessment 3 months after recovery from acute coronavirus disease 2019 (COVID-19). Clin Infect Dis. 2021 Sep 7;73(5): e1089-98. doi: $10.1093 / \mathrm{cid} / \mathrm{ciaa} 1750$.

22. Huang C, Huang L, Wang Y, Li X, Ren L, Gu X, Kang L, et al. 6-month consequences of COVID-19 in patients discharged from hospital: a cohort study. Lancet. 2021 Jan 16;397(10270):220-32. doi: 10.1016/S0140-6736(20)32656-8.

23. Bellan M, Soddu D, Balbo PE, Baricich A, Zeppegno P, Avanzi GC et al. Respiratory and psychophysical sequelae among patients with COVID-19 four months after hospital discharge. JAMA Netw Open. 2021 Jan 4;4(1): e2036142. doi: 10.1001/ jamanetworkopen.2020.36142.

24. Han X, Fan Y, Alwalid O, Li N, Jia X, Yuan M, et al. Sixmonth follow-up chest CT findings after severe COVID-19 pneumonia. Radiology. 2021 Apr;299(1): E177-86. doi: 10.1148/ radiol.2021203153.

25. Truffaut L, Demey L, Bruyneel AV, Roman A, Alard S, De Vos N, et al. Post-discharge critical COVID-19 lung function related to severity of radiologic lung involvement at admission. Respir Res. 2021 Jan 21;22(1):29. doi: 10.1186/s12931-021-01625-y.
26. Liu D, Zhang W, Pan F, Li L, Yang L, Zheng D, et al. The pulmonary sequalae in discharged patients with COVID-19: a short-term observational study. Respir Res. 2020 May 24;21(1):125. doi: 10.1186/s12931-020-01385-1.

27. Marvisi M, Ferrozzi F, Balzarini L, Mancini C, Ramponi S, Uccelli M. First report on clinical and radiological features of COVID-19 pneumonitis in a Caucasian population: Factors predicting fibrotic evolution. Int J Infect Dis. 2020 Oct;99:485-8 doi: $10.1016 /$ j.ijid.2020.08.054.

28. Wei J, Yang H, Lei P, Fan B, Qiu Y, Zeng B, et al. Analysis of thinsection CT in patients with coronavirus disease (COVID-19) after hospital discharge. J Xray Sci Technol. 2020;28(3):383-9. doi: 10.3233/XST-200685.

29. Puntmann VO, Carerj ML, Wieters I, Fahim M, Arendt C, Hoffmann J, et al. Outcomes of cardiovascular magnetic resonance imaging in patients recently recovered From coronavirus disease 2019 (COVID-19). JAMA Cardiol. 2020 Nov 1;5(11):1265-73. doi: 10.1001/jamacardio.2020.3557.

30. Klok FA, Kruip MJHA, van der Meer NJM, Arbous MS, Gommers DAMPJ, Kant KM, et al. Incidence of thrombotic complications in critically ill ICU patients with COVID-19. Thromb Res. 2020 Jul;191:145-7. doi: 10.1016/j. thromres.2020.04.013

31. Patell R, Bogue T, Koshy A, Bindal P, Merrill M, Aird WC, et al. Postdischarge thrombosis and hemorrhage in patients with COVID-19. Blood. 2020 Sep 10;136(11):1342-6. doi: 10.1182/ blood.2020007938.

32. Schulman S, Kearon C; Subcommittee on Control of Anticoagulation of the Scientific and Standardization Committee of the International Society on Thrombosis and Haemostasis. Definition of major bleeding in clinical investigations of antihemostatic medicinal products in non-surgical patients. J Thromb Haemost. 2005 Apr;3(4):692-4. doi: 10.1111/j.15387836.2005.01204.x.

33. Goldhaber SZ, Leizorovicz A, Kakkar AK, Haas SK, Merli G, Knabb RM, et al. ADOPT Trial Investigators. Apixaban versus enoxaparin for thromboprophylaxis in medically ill patients. N Engl J Med. 2011 Dec 8;365(23):2167-77. doi: 10.1056/ NEJMoa1110899.

34. Gibson CM, Halaby R, Korjian S, Daaboul Y, Arbetter DF Yee MK, et al. APEX Investigators. The safety and efficacy of full- versus reduced-dose betrixaban in the Acute Medically Ill VTE (Venous Thromboembolism) Prevention With ExtendedDuration Betrixaban (APEX) trial. Am Heart J. 2017 Mar;185:93100. doi: 10.1016/j.ahj.2016.12.004.

35. Engelen MM, Vandenbriele C, Balthazar T, Claeys E, Gunst J, Guler I, et al. Venous thromboembolism in patients discharged after COVID-19 hospitalization. Semin Thromb Hemost. 2021 Jun;47(4):362-71. doi: 10.1055/s-0041-1727284.

36. Roberts LN, Whyte MB, Georgiou L, Giron G, Czuprynska J, Rea C, et al. Postdischarge venous thromboembolism following hospital admission with COVID-19. Blood. 2020 Sep 10;136(11):1347-50. doi: 10.1182/blood.2020008086.

37. Moldofsky H, Patcai J. Chronic widespread musculoskeletal pain, fatigue, depression and disordered sleep in chronic postSARS syndrome; a case-controlled study. BMC Neurol. 2011 Mar 24;11:37. doi: 10.1186/1471-2377-11-3.

38. Hives L, Bradley A, Richards J, Sutton C, Selfe J, Basu B, et al. Can physical assessment techniques aid diagnosis in people with chronic fatigue syndrome/myalgic encephalomyelitis? A diagnostic accuracy study. BMJ Open. 2017 Nov 13;7(11): e017521. doi: 10.1136/bmjopen-2017-017521.

39. Kida S, Pantazis A, Weller RO. CSF drains directly from the subarachnoid space into nasal lymphatics in the rat. Anatomy, histology and immunological significance. Neuropathol Appl Neurobiol. 1993 Dec;19(6):480-8. doi: 10.1111/j.1365-2990.1993. tb00476.x

40. Montoya JG, Holmes TH, Anderson JN, Maecker HT, RosenbergHasson Y, Valencia IJ, et al. Cytokine signature associated with disease severity in chronic fatigue syndrome patients. Proc Natl Acad Sci U S A. 2017 Aug 22;114(34): E7150-8. doi: 10.1073/ pnas.1710519114.

41. Carruthers BM, van de Sande MI, De Meirleir KL, Klimas NG, Broderick G, Mitchell T, et al. Myalgic encephalomyelitis: 
International Consensus Criteria. J Intern Med. 2011 Oct;270(4):327-38. doi: 10.1111/j.1365-2796.2011.02428.x.

42. Wu Y, Xu X, Chen Z, Duan J, Hashimoto K, Yang L, et al. Nervous system involvement after infection with COVID-19 and other coronaviruses. Brain Behav Immun. 2020 Jul;87:18-22. doi: 10.1016/j.bbi.2020.03.031.

43. Pilotto A, Masciocchi S, Volonghi I, Crabbio M, Magni E, De Giuli V, et al.. Clinical presentation and outcomes of severe acute respiratory syndrome coronavirus 2-related encephalitis: The ENCOVID multicenter study. J Infect Dis. 2021 Jan 4;223(1):28-37. doi: 10.1093/infdis/jiaa609.

44. Gandhi S, Srivastava AK, Ray U, Tripathi PP. Is the collapse of the respiratory center in the brain responsible for respiratory breakdown in COVID-19 patients? ACS Chem Neurosci. 2020 May 20;11(10):1379-81. doi: 10.1021/acschemneuro.0c00217.

45. Li YC, Bai WZ, Hashikawa T. The neuroinvasive potential of SARS-CoV2 may play a role in the respiratory failure of COVID-19 patients. J Med Virol. 2020 Jun;92(6):552-5. doi: 10.1002/jmv.25728.

46. Yong SJ. Persistent brainstem dysfunction in long-COVID: a hypothesis. ACS Chem Neurosci. 2021 Feb 17;12(4):573-80. doi: 10.1021/acschemneuro.0c00793.

47. Lukiw WJ, Pogue A, Hill JM. SARS-CoV-2 Infectivity and neurological targets in the brain. Cell Mol Neurobiol. $2020 \mathrm{Aug}$ 25:1-8. doi: 10.1007/s10571-020-00947-7.

48. Matschke J, Lütgehetmann M, Hagel C, Sperhake JP, Schröder AS, Edler C, et al. Neuropathology of patients with COVID-19 in Germany: a post-mortem case series. Lancet Neurol. 2020 Nov;19(11):919-29. doi: 10.1016/S1474-4422(20)30308-2

49. Meinhardt J, Radke J, Dittmayer C, Franz J, Thomas C, Mothes R, et al. Olfactory transmucosal SARS-CoV-2 invasion as a port of central nervous system entry in individuals with COVID-19. Nat Neurosci. 2021 Feb;24(2):168-75. doi: 10.1038/s41593-02000758-5.

50. Solomon IH, Normandin E, Bhattacharyya S, Mukerji SS, Keller K Ali AS, et al. Neuropathological features of Covid-19. N Engl J Med. 2020 Sep 3;383(10):989-92. doi: 10.1056/NEJMc2019373.

51. Hirsch JS, Ng JH, Ross DW, Sharma P, Shah HH, Barnett RL, et al. Acute kidney injury in patients hospitalized with COVID-19. Kidney Int. 2020 Jul;98(1):209-18. doi: 10.1016/j. kint.2020.05.006.

52. Chan L, Chaudhary K, Saha A, Chauhan K, Vaid A, Zhao S, et al AKI in hospitalized patients with COVID-19. J Am Soc Nephrol. 2021 Jan;32(1):151-60. doi: 10.1681/ASN.2020050615

53. NgJH, Hirsch JS, Hazzan A, Wanchoo R, Shah HH, Malieckal DA, et al. Outcomes among patients hospitalized with COVID-19 and acute kidney injury. Am J Kidney Dis. 2021 Feb;77(2):204-15.e1. doi: 10.1053/j.ajkd.2020.09.002.

54. Bucaloiu ID, Kirchner HL, Norfolk ER, Hartle JE2nd, Perkins RM. Increased risk of death and de novo chronic kidney disease following reversible acute kidney injury. Kidney Int. 2012 Mar;81(5):477-85. doi: 10.1038/ki.2011.405.

55. Leow MK, Kwek DS, Ng AW, Ong KC, Kaw GJ, Lee LS Hypocortisolism in survivors of severe acute respiratory syndrome (SARS). Clin Endocrinol (Oxf). 2005 Aug;63(2):197-202. doi: 10.1111/j.1365-2265.2005.02325.x.

56. Wheatland R. Molecular mimicry of ACTH in SARS - implications for corticosteroid treatment and prophylaxis. Med Hypotheses. 2004;63(5):855-62. doi: 10.1016/j.mehy.2004.04.009.

57. Pal R, Banerjee M. COVID-19 and the endocrine system: exploring the unexplored. J Endocrinol Invest. 2020 Jul;43(7):1027-31. doi: 10.1007/s40618-020-01276-8.

58. Xu J, Zhao S, Teng T, Abdalla AE, Zhu W, Xie L, et al. Systematic Comparison of Two Animal-to-Human Transmitted Human Coronaviruses: SARS-CoV-2 and SARS-CoV. Viruses. 2020 Feb 22;12(2):244. doi: 10.3390/v12020244.

59. Li MY, Li L, Zhang Y, Wang XS. Expression of the SARS-CoV-2 cell receptor gene ACE2 in a wide variety of human tissues. Infect Dis Poverty. 2020 Apr 28;9(1):45. doi: 10.1186/s40249020-00662-x.

60. Brancatella A, Ricci D, Viola N, Sgrò D, Santini F, Latrofa F. Subacute thyroiditis after Sars-COV-2 infection. J Clin Endocrinol Metab. 2020 Jul 1;105(7): dgaa276. doi: 10.1210/ clinem/dgaa276.
61. Ippolito S, Dentali F, Tanda ML. SARS-CoV-2: a potential trigger for subacute thyroiditis? Insights from a case report. J Endocrinol Invest. 2020 Aug;43(8):1171-2. doi: 10.1007/s40618020-01312-7.

62. Asfuroglu Kalkan E, Ates I. A case of subacute thyroiditis associated with Covid-19 infection. J Endocrinol Invest. 2020 Aug;43(8):1173-4. doi: 10.1007/s40618-020-01316-3.

63. Lania A, Sandri MT, Cellini M, Mirani M, Lavezzi E, Mazziotti G. Thyrotoxicosis in patients with COVID-19: the THYRCOV study. Eur J Endocrinol. 2020 Oct;183(4):381-7. doi: 10.1530/EJE-20-0335.

64. Reis FM, Bouissou DR, Pereira VM, Camargos AF, dos Reis AM, Santos RA. Angiotensin-(1-7), its receptor Mas, and the angiotensin-converting enzyme type 2 are expressed in the human ovary. Fertil Steril. 2011 Jan;95(1):176-81. doi: 10.1016/j. fertnstert.2010.06.060.

65. Vaz-Silva J, Carneiro MM, Ferreira MC, Pinheiro SV, Silva DA, Silva-Filho AL, et al. The vasoactive peptide angiotensin-(1-7), its receptor Mas and the angiotensin-converting enzyme type 2 are expressed in the human endometrium. Reprod Sci. 2009 Mar;16(3):247-56. doi: 10.1177/1933719108327593.

66. Jing Y, Run-Qian L, Hao-Ran W, Hao-Ran C, Ya-Bin L, Yang G et al. Potential influence of COVID-19/ACE2 on the female reproductive system. Mol Hum Reprod. 2020 Jun 1;26(6):367-73. doi: 10.1093/molehr/gaaa030.

67. Jin JM, Bai P, He W, Wu F, Liu XF, Han DM, et al. Gender differences in patients with COVID-19: focus on severity and mortality. Front Public Health. 2020 Apr 29;8:152. doi: 10.3389/ fpubh.2020.00152.

68. Klein SL, Flanagan KL. Sex differences in immune responses. Nat Rev Immunol. 2016 Oct;16(10):626-38. doi: 10.1038/ nri.2016.90.

69. Channappanavar R, Fett C, Mack M, Ten Eyck PP, Meyerholz DK, Perlman S. Sex-based differences in susceptibility to severe acute respiratory syndrome coronavirus infection. J Immunol. 2017 May 15;198(10):4046-53. doi: 10.4049/jimmunol.1601896.

70. Robinson DP, Hall OJ, Nilles TL, Bream JH, Klein SL. $17 \beta$-estradiol protects females against influenza by recruiting neutrophils and increasing virus-specific CD8 T cell responses in the lungs. J Virol. 2014 May;88(9):4711-20. doi: 10.1128/ JVI.02081-13

71. Wang Z, Xu X. scRNA-seq profiling of human testes reveals the presence of the ACE2 receptor, a target for SARS-CoV-2 infection in spermatogonia, Leydig and Sertoli cells. Cells. $2020 \mathrm{Apr}$ 9;9(4):920. doi: 10.3390/cells9040920

72. Verma S, Saksena S, Sadri-Ardekani H. ACE2 receptor expression in testes: implications in coronavirus disease 2019 pathogenesis $\uparrow$ Biol Reprod. 2020 Aug 21;103(3):449-51. doi: 10.1093/biolre/ ioaa080.

73. Bahadur G, Acharya S, Muneer A, Huirne J, ukaszuk M, Doreski PA, et al. SARS-CoV-2: diagnostic and design conundrums in the context of male factor infertility. Reprod Biomed Online. 2020 Sep;41(3):365-9. doi: 10.1016/j.rbmo.2020.05.014.

74. Xu J, Qi L, Chi X, Yang J, Wei X, Gong E, et al. Orchitis: a complication of severe acute respiratory syndrome (SARS). Biol Reprod. 2006 Feb;74(2):410-6. doi: 10.1095/ biolreprod.105.044776.

75. Pan F, Xiao X, Guo J, Song Y, Li H, Patel DP, et al. No evidence of severe acute respiratory syndrome-coronavirus 2 in semen of males recovering from coronavirus disease 2019. Fertil Steril. 2020 Jun;113(6):1135-9. doi: 10.1016/j.fertnstert.2020.04.024.

76. La Marca A, Busani S, Donno V, Guaraldi G, Ligabue G Girardis M. Testicular pain as an unusual presentation of COVID-19: a brief review of SARS-CoV-2 and the testis Reprod Biomed Online. 2020 Nov;41(5):903-6. doi: 10.1016/j rbmo.2020.07.017.

77. Gagliardi L, Bertacca C, Centenari C, Merusi I, Parolo E, Ragazzo V, et al. Orchiepididymitis in a boy with COVID-19. Pediatr Infect Dis J. 2020 Aug;39(8): e200-2. doi: 10.1097/ INF.0000000000002769.

78. Fathi M, Vakili K, Aliaghaei A, Nematollahi S, Peirouvi T, Shalizar-Jalali A. Coronavirus disease and male fertility: a systematic review. Middle East Fertil Soc J. 2021;26(1):26. doi: 10.1186/s43043-021-00073-4. 
COVID-19

79. Illiano E, Trama F, Costantini E. Could COVID-19 have an impact on male fertility? Andrologia. 2020 Jul;52(6): e13654. doi: 10.1111/and.13654.

80. Song C, Wang Y, Li W, Hu B, Chen G, Xia P, et al. Absence of 2019 novel coronavirus in semen and testes of COVID-19 patients. Biol Reprod. 2020 Jun 23;103(1):4-6. doi: 10.1093/ biolre/ioaa050.

81. Holtmann N, Edimiris P, Andree M, Doehmen C, BastonBuest D, Adams O, et al. Assessment of SARS-CoV-2 in human semen-a cohort study. Fertil Steril. 2020 Aug;114(2):233-8. doi: 10.1016/j.fertnstert.2020.05.028.

82. Chee YJ, Ng SJH, Yeoh E. Diabetic ketoacidosis precipitated by Covid-19 in a patient with newly diagnosed diabetes mellitus Diabetes Res Clin Pract. 2020 Jun;164:108166. doi: 10.1016/j. diabres.2020.108166.

83. Li J, Wang X, Chen J, Zuo X, Zhang H, Deng A. COVID-19 infection may cause ketosis and ketoacidosis. Diabetes Obes Metab. 2020 Oct;22(10):1935-41. doi: 10.1111/dom.14057.

84. Ren H, Yang Y, Wang F, Yan Y, Shi X, Dong K, et al. Association of the insulin resistance marker TyG index with the severity and mortality of COVID-19. Cardiovasc Diabetol. 2020 May 11;19(1):58. doi: 10.1186/s12933-020-01035-2.

85. Hamming I, Timens W, Bulthuis ML, Lely AT, Navis G, van Goor H. Tissue distribution of ACE2 protein, the functional receptor for SARS coronavirus. A first step in understanding SARS pathogenesis. J Pathol. 2004 Jun;203(2):631-7. doi 10.1002/path.1570.

86. Yang JK, Lin SS, Ji XJ, Guo LM. Binding of SARS coronavirus to its receptor damages islets and causes acute diabetes. Acta Diabetol. 2010 Sep;47(3):193-9. doi: 10.1007/s00592-0090109-4.

87. COVIDIAB registry. Available from: https://covidiab.edendrite.com/index.html [Accessed 25th Sept 2021].

88. Amato MK, Hennessy C, Shah K, Mayer J. Multisystem inflammatory syndrome in an adult. J Emerg Med. 2021 Jul;61(1): e1-3. doi: 10.1016/j.jemermed.2021.02.007.

89. Belot A, Antona D, Renolleau S, Javouhey E, Hentgen V, Angoulvant F, et al. SARS-CoV-2-related paediatric inflammatory multisystem syndrome, an epidemiological study, France, 1 March to 17 May 2020. Euro Surveill. 2020 Jun;25(22):2001010. doi: 10.2807/1560-7917.ES.2020.25.22.2001010.

90. Morris SB, Schwartz NG, Patel P, Abbo L, Beauchamps L, Balan S, et al. Case series of multisystem inflammatory syndrome in adults associated with SARS-CoV-2 infection United Kingdom and United States, March-August 2020 MMWR Morb Mortal Wkly Rep. 2020 Oct 9;69(40):1450-6. doi: 10.15585/mmwr.mm6940e1.

91. Toubiana J, Poirault C, Corsia A, Bajolle F, Fourgeaud J, Angoulvant F, et al. Kawasaki-like multisystem inflammatory syndrome in children during the covid-19 pandemic in Paris, France: prospective observational study. BMJ. 2020 Jun 3;369: m2094. doi: 10.1136/bmj.m2094.

92. Whittaker E, Bamford A, Kenny J, Kaforou M, Jones CE, Shah P, et al. Clinical characteristics of 58 children with a pediatric inflammatory multisystem syndrome temporally associated with SARS-CoV-2. JAMA. 2020 Jul 21;324(3):259-69. doi: 10.1001/ jama.2020.10369.

93. Roe K. A viral infection explanation for Kawasaki disease in general and for COVID-19 virus-related Kawasaki disease symptoms. Inflammopharmacology. 2020 Oct;28(5):1219-22 doi: $10.1007 / \mathrm{s} 10787-020-00739-\mathrm{x}$.

94. Sollini M, Ciccarelli M, Cecconi M, Aghemo A, Morelli P, Gelardi F, et al. Vasculitis changes in COVID-19 survivors with persistent symptoms: an [18F]FDG-PET/CT study. Eur J Nucl Med Mol Imaging. 2021 May;48(5):1460-6. doi: 10.1007/ s00259-020-05084-3.

95. Zhou M, Yin Z, Xu J, Wang S, Liao T, Wang K, et al. Inflammatory profiles and clinical features of COVID-19 survivors three months after discharge in Wuhan, China. J Infect Dis. 2021 Apr 4: jiab181. doi: 10.1093/infdis/jiab181.

96. Kucuk A, Cumhur Cure M, Cure E. Can COVID-19 cause myalgia with a completely different mechanism? A hypothesis Clin Rheumatol. 2020 Jul;39(7):2103-4. doi: 10.1007/s10067020-05178-1.
97. Lacourt TE, Vichaya EG, Chiu GS, Dantzer R, Heijnen CJ. The high costs of low-grade inflammation: persistent fatigue as a consequence of reduced cellular-energy availability and nonadaptive energy expenditure. Front Behav Neurosci. 2018 Apr 26;12:78. doi: 10.3389/fnbeh.2018.00078.

98. Lamers MM, Beumer J, van der Vaart J, Knoops K, Puschhof J, Breugem TI, et al. SARS-CoV-2 productively infects human gut enterocytes. Science. 2020 Jul 3;369(6499):50-4. doi: 10.1126/ science.abc1669.

99. Xiao F, Tang M, Zheng X, Liu Y, Li X, Shan H. Evidence for Gastrointestinal Infection of SARS-CoV-2. Gastroenterology 2020 May;158(6):1831-33.e3. doi: 10.1053/j.gastro.2020.02.055.

100. Zang R, Gomez Castro MF, McCune BT, Zeng Q, Rothlauf PW, Sonnek NM, et al. TMPRSS2 and TMPRSS4 promote SARS$\mathrm{CoV}-2$ infection of human small intestinal enterocytes. Sci Immunol. 2020 May 13;5(47): eabc3582. doi: 10.1126 / sciimmunol.abc3582.

101. Cheung KS, Hung IFN, Chan PPY, Lung KC, Tso E, Liu R, et al. Gastrointestinal manifestations of SARS-CoV-2 infection and virus load in fecal samples from a Hong Kong cohort: systematic review and meta-analysis. Gastroenterology. 2020 Jul;159(1):8195. doi: 10.1053 /j.gastro.2020.03.065.

102. Mao R, Qiu Y, He JS, Tan JY, Li XH, Liang J, et al. Manifestations and prognosis of gastrointestinal and liver involvement in patients with COVID-19: a systematic review and meta-analysis. Lancet Gastroenterol Hepatol. 2020 Jul;5(7):667-78. doi: 10.1016/S2468-1253(20)30126-6

103. Liang L, Yang B, Jiang N, Fu W, He X, Zhou Y, et al. Threemonth follow-up study of survivors of coronavirus disease 2019 after discharge. J Korean Med Sci. 2020 Dec 7;35(47): e418. doi: 10.3346/jkms.2020.35.e418.

104. Petersen MS, Kristiansen MF, Hanusson KD, Danielsen ME, Á Steig B, Gaini S, et al. Long COVID in the Faroe Islands - a longitudinal study among non-hospitalized patients. Clin Infect Dis. 2020 Nov 30: ciaa1792. doi: 10.1093/cid/ciaa1792.

105. Zhao YM, Shang YM, Song WB, Li QQ, Xie H, Xu QF, et al. Follow-up study of the pulmonary function and related physiological characteristics of COVID-19 survivors three months after recovery. EClinicalMedicine. 2020 Aug;25:100463. doi: 10.1016/j.eclinm.2020.100463.

106. Yeoh YK, Zuo T, Lui GC, Zhang F, Liu Q, Li AY, et al. Gut microbiota composition reflects disease severity and dysfunctional immune responses in patients with COVID-19. Gut. 2021 Apr;70(4):698706. doi: 10.1136/gutjnl-2020-323020.

107. Zuo T, Zhan H, Zhang F, Liu Q, Tso EYK, Lui GCY, et al. Alterations in fecal fungal microbiome of patients with COVID-19 during time of hospitalization until discharge. Gastroenterology 2020 Oct;159(4):1302-10.e5. doi: 10.1053/j.gastro.2020.06.048.

108. Troyer EA, Kohn JN, Hong S. Are we facing a crashing wave of neuropsychiatric sequelae of COVID-19? Neuropsychiatric symptoms and potential immunologic mechanisms. Brain Behav Immun. 2020 Jul;87:34-9. doi: 10.1016/j.bbi.2020.04.027.

109. Broderick G, Fuite J, Kreitz A, Vernon SD, Klimas N, Fletcher MA. A formal analysis of cytokine networks in chronic fatigue syndrome. Brain Behav Immun. 2010 Oct;24(7):1209-17. doi: $10.1016 /$ j.bbi.2010.04.012

110. Ackermann M, Verleden SE, Kuehnel M, Haverich A, Welte T, Laenger F, et al. Pulmonary vascular endothelialitis, thrombosis, and angiogenesis in Covid-19. N Engl J Med. $2020 \mathrm{Jul}$ 9;383(2):120-8. doi: 10.1056/NEJMoa2015432.

111. Afrin LB, Weinstock LB, Molderings GJ. Covid-19 hyperinflammation and post-Covid-19 illness may be rooted in mast cell activation syndrome. Int J Infect Dis. 2020 Nov; 100:32732. doi: $10.1016 /$ j.ijid.2020.09.016

112. Kazama I. Stabilizing mast cells by commonly used drugs: a novel therapeutic target to relieve post-COVID syndrome? Drug Discov Ther. 2020 Nov 4;14(5):259-61. doi: 10.5582/ddt.2020.03095.

113. Gebremeskel S, Schanin J, Coyle KM, Butuci M, Luu T, Brock EC, et al. Mast cell and eosinophil activation are associated with COVID-19 and TLR-mediated viral inflammation: implications for an anti-siglec-8 antibody. Front Immunol. 2021 Mar 10;12:650331. doi: 10.3389/fimmu.2021.650331.

114. Zhou Z, Ren L, Zhang L, Zhong J, Xiao Y, Jia Z, et al. Heightened innate immune responses in the respiratory tract of COVID-19 
patients. Cell Host Microbe. 2020 Jun 10;27(6):883-90.e2. doi: 10.1016/j.chom.2020.04.017.

115. Needham DM, Davidson J, Cohen H, Hopkins RO, Weinert C Wunsch $\mathrm{H}$, et al. Improving long-term outcomes after discharge from intensive care unit: report from a stakeholders' conference. Crit Care Med. 2012 Feb;40(2):502-9. doi: 10.1097/ CCM.0b013e318232da75.

116. Greenhalgh T, Knight M. Long COVID: A Primer for Family Physicians. Am Fam Physician. 2020 Dec 15;102(12):716-7.

\section{Clinical manifestation of post-COVID-19 syndrome}

\author{
M.D. Tronko, V.L. Orlenko, Yu.V. Kurinna, K.Yu. Ivaskiva \\ SI «V.P. Komisarenko Institute of Endocrinology and Metabolism of the \\ National Academy of Medical Sciences of Ukraine»
}

\begin{abstract}
Nowadays, the COVID-19 pandemic has been going on for about two years. Although the knowledge of specialists has significantly improved in the prevention and treatment of severe forms of the disease, but the pathogenesis and treatment of postCOVID-19 syndrome remain relevant issues in the medical and scientific communities. The urgency of the problem is the significant spreading of this condition among patients, reduced quality of patients life, lack of knowledge about the frequency, mechanisms and causes of long-term COVID-19 consequences, unclear ideas about approaches to diagnosis and treatment, and lack of regulations for such patients. The term post-COVID-19 was firstly proposed in August 2020 by British researchers. The existing evidence suggests large variations in estimates of the prevalence and incidence of post-covid syndrome because of the differences in study populations, recruitment methods, follow-up periods, and sample sizes. The incidence of post-COVID syndrome is estimated at $10-35 \%$, while for hospitalized patients it can reach $85 \%$. Fatigue is the most common symptom reported in $17.5-72 \%$ of post-COVID cases, followed by residual dyspnea with an incidence ranging from $10-40 \%$, followed by mental problems, chest pain, olfactory and taste dysfunction occurring in 26, 22 and $11 \%$ of reconvalescents, respectively. More than one third of patients with postCOVID syndrome have pre-existing comorbidities, hypertension and diabetes mellitus being the most common. Data published to date suggest that most patients with post-COVID-19 syndrome have a good prognosis without further complications and lethal consequences. Most studies so far have focused on symptoms associated with post-covid syndrome rather than organ dysfunction. The review presents an analysis of research to determine post-COVID-19 syndrome, the study of the impact of the infection consequences on different organ systems and the main potential mechanisms for the development of complications. Particular attention is paid to the effects of COVID-19 on endocrine organs. Recommendations for examination and management of patients with post-COVID-19 syndrome are offered.
\end{abstract}

Keywords: post-COVID-19 syndrome, pathogenesis, diagnosis, clinic, treatment.

\section{Клинические проявления синдрома пост-COVID-19}

\section{Н.Д. Тронько, В.Л. Орленко, Ю.В. Куренная, \\ Е.Ю. Иваськива}

ГУ «Институт эндокринологии и обмена веществ им. В.П. Комиссаренко НАМН Украины»

Резюме. На сегодня пандемия COVID-19 длится уже около двух лет. Хотя знания специалистов значительно улучшились в вопросах профилактики и лечения тяжелых форм заболевания, патогенез и лечение синдрома пост-COVID-19 остаются актуальными вопросами в медицинском и научном сообществах. Актуальность проблемы заключается в значительном распространении этого состояния среди переболевших, снижении качества жизни паци ентов, недостатка знаний о частоте, механизмах протекания и причинах отдаленных последствий, нечетких представлениях о подходах к диагностике и лечению, а также отсутствии нормативных документов по ведению таких больных. В августе 2020 года, британскими исследователями впервые был предложен термин постCOVID-19. Имеющиеся данные свидетельствуют о значительных различиях в эпидемиологических оценках распространенности постковидного синдрома из-за различий в методах отбора, периодах наблюдения и размерах выборок. Частота пост-COVID-19 синдрома оценивается в 10-35\%, тогда как для госпитализированных пациентов она может достигать и 85\%. Утомляемость является наиболее распространенным симптомом, о котором сообщается в 17,5-72,0\% случаев после перенесенного COVID-19, затем вслед за одышкой, частота которой составляет 10-40\% идут психические проблемы, боль в груди, обонятельная и вкусовая дисфункция, встречаются соответственно до 26, 22 и 11\% реконвалесцентов. Более одной трети пациентов с пост-COVID-19 синдромом имеют сопутствующие заболевания, чаще всего встречаются гипертония и сахарный диабет. Имеющиеся опубликованные данные свидетельствуют о том, что большинство пациентов с пост-COVID-19 синдромом имеют хороший прогноз без дальнейших осложнений и летальных исходов. Большинство исследований до сих пор были сосредоточены на симптомах, связанных с постковидным синдромом, а не на дисфункции органов. В обзоре представлен анализ исследований по определению синдрома пост-COVID-19, изучение влияния перенесенной инфекции на различные системы органов и представлены основные потенциальные механизмы развития осложнений. Особое внимание уделено последствиям перенесенного COVID-19 со стороны эндокринных органов. Предложенные рекомендации по обследованию и ведению пациентов с пост-COVID-19 синдромом.

Ключевые слова: синдром пост-COVID-19, патогенез, диагностика, клиника, лечение.

Для цитування: Тронько МД, Орленко ВЛ, Курінна ЮВ, Іваськіва КЮ. Клінічні прояви синдрому пост-COVID-19. Ендокринологія. 2021;26(3):248-262. DOI: 10.31793/1680-1466.2021.26-3.248. 
COVID-19

Адреса для листування: Орленко Валерія Леонідівна, orleva@ukr. net; ДУ «Інститут ендокринології та обміну речовин ім. В.П. Комісаренка НАМН України», вул. Вишгородська, 69, Київ 04114, Україна.

Відомості про авторів: Тронько Микола Дмитрович, д-р мед. наук, проф., чл.-кор. НАН України, акад. НАМН України, завідувач відділу фундаментальних і прикладних проблем ендокринології, директор, ORCID: 0000-0001-7421-0981; Орленко Валерія Леонідівна, д-р мед. наук, старш. наук. співроб., завідувач науково-консультативного відділу амбулаторно-профілактичної допомоги хворим з ендокринною патологією, ORCID: 0000-0002-8400-576X; Курінна Юлія Вікторівна, мол. наук. співроб. науково-консультативного відділу амбулаторно-профілактичної допомоги хворим з ендокринною патологією, ORCID: 0000-0001-8404-2424; Іваськіва Катерина Юріівна, старш. наук. співроб. науково-консультативного відділу амбулаторно-профілактичної допомоги хворим з ендокринною патологією, ORCID: 0000-0003-1680-4663.

Особистий внесок: Тронько М.Д. - ідея роботи, участь у розробці концепції статті; Орленко В.Л. - ідея роботи, участь у розробці концепції статті, підбір та аналіз літературних джерел, консультування під час редагування статті, написання, оформлення, підготовка до друку статті; Курінна Ю.В. - підбір та аналіз літературних джерел, написання тексту, оформлення, підготовка до друку статті; Іваськіва К.Ю. - аналіз літературних джерел, оформлення, підготовка до друку статті.

Фінансування: стаття підготовлена в рамках бюджетного фінансування за планом науково-дослідних робіт ДУ «нститут ендокринології та обміну речовин ім. В.П. Комісаренка НАМН України» (№ державної реєстрації: 0120U100644).

Декларація з етики: автори задекларували відсутність конфлікту інтересів і фінансових зобов'язань.

Стаття: надійшла до редакції 27.09 .2021 р.; перероблена 30.09.2021 р.; прийнята до друку 01.10.2021 р.; надрукована 20.10.2021 p.

For citation: Tronko MD, Orlenko VL, Kurinna YuV, Ivaskiva KYu. Clinical manifestation of post-COVID-19 syndrome. Endokrynologia. 2021;26(3):248-262. DOI: 10.31793/1680-1466.2021.26-3.248.

Correspondence address: Valeriia Leonidivna Orlenko, orleva@ukr. net, SI «V.P. Komisarenko Institute of Endocrinology and Metabolism of the NAMS of Ukraine», Vyshgorodska Str., 69, Kyiv 04114, Ukraine.

Information about the authors: Tronko Mykola Dmytrovych, Dr. Sci. (Medicine), Prof., Cor. Member of the NAS of Ukraine, Acad. of the NAMS of Ukraine, Head of the Department of Fundamental and Applied Problems of Endocrinology, Director, ORCID: 0000-00017421-0981; Orlenko Valeriia Leonidivna, MD, PhD, Head of Department of Scientific and Advisory Preventive Care for Patients with Endocrine Disorders, ORCID: 0000-0002-8400-576X; Kurinna Yuliia Viktorivna, Researcher of Department of Scientific and Advisory Preventive Care for Patients with Endocrine Disorders, ORCID: 0000-0001-8404-2424 Ivaskiva Kateryna Yuriivna, MD, PhD, Senior Researcher of Department of Scientific and Advisory Preventive Care for Patients with Endocrine Disorders, ORCID: 0000-0003-1680-4663.

Personal contribution: Tronko M.D. - the idea of work, participation in the development of the concept of the article; Orlenko V.L. - idea of work, participation in the development of the concept of the article, selection and analysis of literary sources, consulting during the editing of the article, writing, design, preparation for publication of the article; Kurinna Yu.V. — selection and analysis of literary sources, writing the text, design, preparation for publication of the article; Ivaskiva K. Yu. - analysis of literary sources, design, preparation for publication of the article.

Funding: The article was prepared within the budget funding according to the plan of research work of the State Institution «V.P. Komisarenko Institute of Endocrinology and Metabolism of the NAMS of Ukraine» (State registration number: 0120U100644).

Declaration of ethics: the authors declared the absence of a conflict of interest and financial obligation.

Article: received 27 September 2021; revised 30 September 2021; accepted 01 October 2021; published 20 October 2021.

Для цитирования: Тронько НД, Орленко ВЛ, Куренная ЮВ, Иваськива ЕЮ. Клинические проявления синдрома пост-COVID-19. Эндокринология. 2021;26(3):248-262. DOI: 10.31793/16801466.2021.26-3.248.

Адрес для переписки: Орленко Валерия Леонидовна, orleva@ ukr.net; ГУ «Институт эндокринологии и обмена веществ им. В.П. Комиссаренко НАМН Украины», ул. Вышгородская, 69, г. Киев 04114, Украина.

Сведения об авторах: Тронько Николай Дмитриевич, д-р мед. наук, проф., чл.-корр. НАН Украины, акад. НАМН Украины, заведующий отделом фундаментальных и прикладных проблем эндокринологии, директор, ORCID: 0000-0001-7421-0981; Орленко Валерия Леонидовна, д-р мед. наук, старш. науч. сотр., заведующая научно-консультативного отдела амбулаторно-профилактической помощи больным с эндокринной патологией, ORCID: 00000002-8400-576Х; Куренная Юлия Викторовна, мл. науч. сотр. научно-консультативного отдела амбулаторно-профилактической помощи больным с эндокринной патологией, ORCID: 0000-00018404-2424; Иваськива Екатерина Юрьевна, старш. науч. сотр. научно-консультативного отдела амбулаторно-профилактической помощи больным с эндокринной патологией, ORCID: 0000-00031680-4663

Личный вклад: Тронько М.Д. - идея работы, участие в разработке концепции статьи; Орленко В.Л. - идея работы, участие в разработке концепции статьи, подбор и анализ литературных источников, консультирование при редактировании статьи, написание, оформление, подготовка к печати статьи; Куринная Ю.В. подбор и анализ литературных источников, написание текста, оформление, подготовка к печати статьи; Иваськива Е.Ю. - анализ литературных источников, оформление, подготовка к печати статьи.

Финансирование: статья подготовлена в рамках бюджетного финансирования по плану научно-исследовательских работ ГУ «Институт эндокринологии и обмена веществ им. В.П. Комиссаренко НАМН Украины» (№ государственной регистрации: 0120U100644).

Декларация по этике: авторы задекларировали отсутствие конфликта интересов и финансовых обязательств.

Статья: поступила в редакцию 27.09.2021 г.; переработана 30.09.2021 г.; принята в печать 01.10.2021 г.; напечатана 20.10.2021 г. 